Article

\title{
Expert Ministers in New Democracies: Delegation, Communist Legacies, or Technocratic Populism?
}

\author{
Elena Semenova \\ Institute of Political Science, Free University of Berlin, 14195 Berlin, Germany; E-Mail: elena.semenova@fu-berlin.de
}

Submitted: 25 June 2020 | Accepted: 2 November 2020 | Published: 17 December 2020

\begin{abstract}
This article examines the appointments and survival of expert ministers (i.e., ministers with educational and professional expertise in the portfolio to which they are appointed) in new democracies. Using a novel data set on 11 Central and Eastern European countries from 1990 until 2012, I test competing hypotheses derived from delegation theory, communist legacies approach, technocratic populism studies, and semi-presidentialism literature. The first study shows that experts without political experience (technocrats) have specific cabinet appointment patterns distinguishing them from party politicians and politically experienced experts. For example, technocrats have high chances of being appointed during an economic downturn. The conditional risk set survival analysis has revealed that compared to their politically experienced colleagues, technocrats have higher chances of remaining in their positions if there was a change in the PM's candidacy. Moreover, they have long careers independently of the continuity of the PM's party in government and the PM's partisan status. Strikingly, patterns of portfolio specialization from the communist period remained in place after the regime change (e.g., expert ministers holding the portfolios of finance and economy). However, holding these specific portfolios does not decrease the minister's risk of being dismissed. These findings have ramifications for issues surrounding cabinet formation, institutional choice, and populism in new democracies.
\end{abstract}

\section{Keywords}

communist legacies; economic crisis; politically experienced experts; post-communism; semi-presidentialism; technocracy; technocratic populism

\section{Issue}

This article is part of the issue "Varieties of Technocratic Populism around the World" edited by Petra Guasti (Institute of Sociology of the Czech Academy of Sciences, Czech Republic) and Lenka Buštíková (Institute of Sociology of the Czech Academy of Sciences, Czech Republic / Arizona State University, USA).

(C) 2020 by the author; licensee Cogitatio (Lisbon, Portugal). This article is licensed under a Creative Commons Attribution 4.0 International License (CC BY).

\section{Introduction}

Populism and populists are on the rise around the world. What unites populists is the appeal to 'ordinary people' and the massive critique of the 'political establishment' -although these politicians might have been an integral part of this establishment themselves (e.g., Donald Trump in the United States). Populists argue that 'the people' are the sovereign that was robbed of their sovereignty by 'the corrupt elites' and only they, the populists, can restore justice (e.g., Mudde, 2004). Populism has been seen as an alternative to party democracy. Technocracy, or the governance by technical exper- tise, is allegedly another alternative (Caramani, 2017). Recently, a new form of populism well known from Latin American context (e.g., Rafael Correa in Ecuador) has begun to appear in European countries, exemplified by Emmanuel Macron of France and Andrej Babiš of the Czech Republic. Using a technocratic approach, these politicians connect populist promises to politics, claiming to produce better policies in a more efficient way (e.g., Buštíková \& Guasti, 2019; Havlík, 2019). Technocratic populism represents a new threat to party democracy and, therefore, warrants close examination.

Studies of technocratic populism have provided crucial insights for a better understanding of presidential 
leadership (e.g., de la Torre, 2013), and the political style of techno-populist prime ministers (e.g., Buštíková \& Guasti, 2019; Havlík, 2019; Valbruzzi, 2018; see also contributions on France, Italy, and Georgia in this thematic issue). Researchers have also looked at technopopulist policy agenda setting and policy implementation, particularly in the Latin American context (e.g., de la Torre, 2013; Roberts, 1995). One understudied aspect of technocratic populism is how populists use technocracy as a strategy to realize their policy preferences and gain public support. The most apparent strategy is to use technocratic discourse during political campaigns (e.g., Buštíková \& Guasti, 2019). Another strategy-complementary to the first one-is to appoint technocrats to government. In doing so, politicians signal to other parties and to the electorate that not only they will run the state efficiently, but also that they know the right persons to do this job on their behalf (see also contribution on Italy in this thematic issue). The latter aspect (i.e., the reasons for technocratic appointments to governments) is the focus of this article.

I argue that new democracies of Central and Eastern Europe provide a fruitful ground for using technocratic expertise in government for two reasons. The first is party systems' weakness and blurred societal cleavages in these countries (e.g., Whitefield, 2002). After decades of communist domination, the transition to democracy provided a unique window of opportunities for new parties (Lewis, 2002). Despite developing under challenging conditions (e.g., the lack of territorial party organizations, high electoral and party volatility, and strategically disloyal behavior of politicians; see, e.g., Semenova, 2015; Tavits, 2005), party systems in new democracies have become more consolidated over time. Since the 2000s, party systems of new democracies have become more fragmented. Unorthodox parties of various stances-including (centrist) populist parties with the high personalization of leadership and technocratic appeal-have emerged and became electorally successful (e.g., Pop-Eleches, 2010). The electoral success of newly emerged unorthodox parties has been considered one of the reasons for an increased demand for technocracy and technocrats in new democracies (e.g., Buštíková \& Guasti, 2019). The second reason is a generally positive perception of technocracy and technocrats among the public and politicians of new democracies (e.g., Bertsou \& Pastorella, 2017). I argue that public preference for technocracy originated in the late communist period, when professional expertise in the respective policy area became the primary credential for a government position (e.g., Hanley \& Treiman, 2005). These communist legacies have continued to affect cabinet formation in new democracies even after the collapse of communism (Semenova, 2018).

This article examines the appointment of expert ministers (i.e., ministers with educational and professional expertise in the portfolio to which they are appointed) to cabinets in 11 post-communist countries of Central and Eastern Europe. In doing so, I consider two research questions. The first is under what circumstances a minister's expertise has been an important credential for being appointed to a cabinet. The second question is how the PMs and popularly elected presidents influence the survival of ministers in post-communist countries. Using delegation theory, semi-presidentialism, technocratic populism, and communist legacy studies, I show that the value of expertise differs among ministers with and without political experience. The results of a binary logistic regression estimated in this article have shown that experts without political experience have specific appointment patterns distinguishing them from party politicians in government. Using a conditional risk set Cox regression model, I provide evidence that technocrats have different patterns of survival in cabinet compared to their politically experienced colleagues.

This article contributes to the existing literature in four ways. First, it demonstrates that expert ministers with different profiles are more likely to be appointed under specific institutional, political, and cultural circumstances. Although scholars have addressed the appointment of ministers recruited from outside of parliaments (also experts, e.g., Neto \& Strøm, 2006; Semenova, 2018), few have considered experts specifically (but see, Bertsou \& Caramani, 2020) or delineated the effects of political, institutional, and economic determinants on the recruitment of different types of expert ministersboth of which this article seeks to do. Second, this article contributes to the literature on the effects of economic and political crises on the appointment of experts (e.g., Pastorella, 2016) by showing that, in post-communist countries, a poor economic situation is a decisive factor in the appointment of technocrats but not of expert ministers with political experience. Third, this article contributes to the discussion of communist legacies (e.g., Kitschelt, 1995) by demonstrating how recruitment and portfolio allocation patterns originated in the communist period effect ministerial appointments in the post-communist period. Fourth, the article contributes to the literature on ministerial survival by showing differences in the survival of technocrats and politically experienced ministers. This article introduces the original data set on ministerial recruitment in 11 new EU Members states of Central and Eastern Europe. The findings presented in this study have ramifications for issues surrounding cabinet formation, ministerial careers, institutional choice, populism, and party politics in new democracies.

\section{Cabinet Appointment of Expert Ministers: Theoretical Considerations}

The appointments of technocrats (i.e., ministers those primary credentials are their professional expertise and not their party experience) expose two theoretical divides in the literature. The first is whether party democracy is the dominant model of the political process or 
there are alternatives to it. The second is whether the party government is the best strategy to govern. In studies on cabinet formation, these divides often operationalize through the value of political experience versus expertise for ministers.

Starting with the question about party democracy, most approaches to ministerial appointments can be arranged between delegation theory and technocratic populism, representing the opposite sides of this continuum. Delegation theory embraces party democracy. It considers the formation of cabinet is just a step in the delegation chain, i.e., the voters elect political parties; the winning political parties build a government and select the PM who is, in turn, in charge of selecting their ministers (Strøm, Müller, \& Bergman, 2008). Delegation theory predicts two important factors for the understanding of ministerial appointments. The first is that the relationship between the PM and their ministers may be conflicted because of the asymmetry of information between the sides and the possibility that ministers may pursue a hidden agenda. The second is that the PM and political parties try to minimize delegation conflicts by carefully screening the candidates for a ministerial position and testing their political loyalty. Parliaments and party organizations are the best platforms for such screening because the principals have a large number of candidates whom they may observe over a longer period (e.g., Blondel \& Thiébault, 1991; Dowding \& Dumont, 2009; Huber \& Martinez-Gallardo, 2008).

In contrast, technocratic populism rejects party democracy and mainstream parties of all ideological orientations (Bickerton \& Invernizzi Accetti, 2017). Like other types of populism, technocratic populists criticize political parties and other institutes of mediation as unnecessary and prone to manipulation and corruption (Bickerton \& Invernizzi Accetti, 2017). They also criticize the ideas of procedural legitimacy by arguing that the source of legitimacy is 'the ordinary people.' Instead, "technocratic populism strategically uses the appeal of technocratic competence and weaponizes numbers to deliver a populist message" (Buštíková \& Guasti, 2019, p. 304). For technocratic populists, ministers with political experience represent the 'establishment' and should, therefore, be excluded from the pool of ministeriables.

These approaches also oppose each other in their perception of whether party government is the best available option to govern, a question related to the value of professional expertise for cabinet ministers. For delegation theory, the minister's professional expertise does not play any prominent role. Indeed, it expects that ministers provide political guidance according to their party's preferences, while professional expertise is provided by bureaucrats in the respective ministries (Huber, 2000). Delegation theory suggests that the appointments of experts increase the asymmetry of information between the PM and the minister, which may allow expert ministers to extract greater benefits from their position-either in terms of policy or material assets-than the PM would like. Sometimes, experts must be appointed (e.g., because of public expectations that a good performance in some portfolios can only be achieved by experts; see Bakema \& Secker, 1988). Nevertheless, the delegation theory predicts that these expert ministers will have political experience because the minister's party loyalty will decrease the probability of delegation problems between the PM and her ministers and ensure party preferences in the policy areas controlled by expert ministers.

For delegation theory, the appointments of expert ministers without political experience (i.e., technocrats) are dysfunctional. Researchers on parliamentary systems characterize these appointments as a consequence of a political (e.g., coalition conflicts) or economic crisis (Alexiadou \& Gunaydin, 2019; McDonnell \& Valbruzzi, 2014; Pastorella, 2016). However, the appointment of politically inexperienced experts is often of a short duration. Delegation theory expects that after crisis climaxes, the party government will be reinstalled, and politically experienced ministers will replace their technocratic counterparts (e.g., Semenova, 2018; Yong \& Hazell, 2011).

Technocratic populism, in contrast, maintains that only technocrats can provide solutions to the problems that are relevant to the entire society, as opposed to particularistic decision-making essential to party government (e.g., Bickerton \& Invernizzi Accetti, 2017; Havlík, 2019). Appointing technocrats is a crucial strategy for increasing the legitimacy of the populist government and creating public acceptance for neoliberal reforms (e.g., Buštíková \& Guasti, 2019; Roberts, 1995). Moreover, during political crises, populists prefer to appoint technocrats in order to make their government functional and less conflictual (Pastorella, 2016; Valbruzzi, 2018).

Between both approaches (i.e., delegation theory and technocratic populism) lie semi-presidentialism and communist legacies approaches. Similar to technocratic populism, semi-presidential studies consider the appointments of politically inexperienced ministers rational. Scholars have maintained that in semipresidentialism-where PMs have to share executive powers with the popularly elected president (Elgie, 1999, p. 13)-the presidents have greater institutional powers to influence the government formation, for instance, by refusing to confirm the ministers proposed by the PM or even appointing some ministers discretionally (Semenova \& Dowding, 2019; Tavits, 2009). Furthermore, non-partisan ministers promoted by the president are considered his natural allies; therefore, their appointments are just one strategy to ensure the realization of presidential policy preferences in government (Neto \& Strøm, 2006; Schleiter \& Morgan-Jones, 2009; Tavits, 2009). Most importantly, the survival of such ministers depends on presidential support (Semenova, 2018; Semenova \& Dowding, 2019). Unlike technocratic populism, semi-presidentialism studies do not examine the importance of the minister's expertise for cab- 
inet appointments. Presidential appointees have to be non-partisan, although they may also be experts (e.g., Tavits, 2009).

Finally, communist legacy studies suggest that the ministers' professional experience is the most critical criterion for their appointments. I posit that two communist legacies are particularly influential. The first is the importance of a professional education and relevant occupational experience for ministers. As scholars on communist politics have underlined (e.g., Harasymiw, 1984), from the early 1970 s until the collapse of communism, political (i.e., within the Communist Party hierarchy) and professional careers (including ministerial positions) were largely separated and required different credentials. For entry to party positions, political loyalty was the major credential. For entry into professional positions, tertiary education and relevant occupational experience were necessary (Hanley \& Treiman, 2005; Hough, 1973, p. 6). Using the legacy argument, I expect that this pattern continued to be in place after the regime change, particularly in countries with high political continuity after the collapse of communism. The second legacy that might survive the collapse of communism is the pattern of specialization within bureaucratic organizations. As Hough (1973, pp. 142-143) has revealed, in the Soviet Union, some policy areas were more often occupied than others by bureaucrats with relevant educational and professional experience. Among these policy areas were government positions in the military, economy, health, education, science, and technology. Because many practices developed in the Soviet Union were later adopted by other communist countries (e.g., Hanley \& Treiman, 2005), I assume that other communist countries shared these preferences for experts in the aforementioned policy areas. These preferences were also likely to survive the collapse of communism because technocratic leadership as a form of governance enjoys strong public support in former communist countries (Bertsou \& Pastorella, 2017).

By stressing the minister's expertise as a significant credential for cabinet appointments, communist legacies studies resemble the technocratic populism approach. However, the legacies approach does not reject ministers with political experience from the ministerables, as technocratic populists do. Instead, the legacies approach considers expert ministers the norm rather than the dysfunctional exception. It expects that both PMs and popularly elected presidents should actively appoint such ministers (independently of their political experience).

To test the expectations derived from four types of literature (i.e., delegation theory, technocratic populism, semi-presidentialism, and communist legacies), I conducted two studies. The first study dealt with the determinants of the appointments of expert ministers to cabinets in post-communist countries. It answered questions about who is selected and under what circumstances. The second study analyzed the determinants of ministerial tenures in cabinets; to this end, the research question concerns who remains in cabinets longer and what that tells us about the power of PMs and presidents.

\section{The Operationalization of Expert Ministers}

This article will focus on the appointments of two groups of expert ministers. The first group consists of ministers who are experts in their policy area (i.e., they have advanced educational training and relevant professional experience; see Camerlo \& Pérez-Liñán, 2015, p. 318) and they had no parliamentary or party-leading experience (compare McDonnell \& Valbruzzi, 2014); I define these ministers as technocrats. The second group includes ministers who are experts in their policy area with parliamentary and/or party-leading experience; these ministers are politically experienced experts. Because membership in each of these groups is counted at the time of the minister's first appointment to cabinet, it is mutually exclusive. The residual category includes party politicians (i.e., politicians with leading party and/or parliamentary experience) without expertise in their portfolio.

\section{The Determinants of the Appointments of Experts to Central and Eastern European Cabinets}

\subsection{Hypotheses and Indicators}

Each type of the literature (i.e., delegation theory, semipresidentialism, technocratic populism, and communist legacies approaches) predict the recruitment of ministers with different types of credentials. The delegation theory predicts that experts are recruited to the cabinet if PMs and presidents have powers to do so (the political opportunity argument) and if they have an increased need for expertise during crises. Starting with the political opportunity argument, the type of cabinet is expected to structure the PM's opportunities to appoint expert ministers (see the Supplementary File for indicators and descriptive statistics). Compared to minority cabinets, in majority cabinets, PMs have a larger pool of candidates from which to recruit (Huber \& Martinez-Gallardo, 2008). Therefore, I expected that minority cabinets will have fewer technocrats and fewer politically experienced experts than their majority counterparts ( $\mathrm{H} 1 \mathrm{a})$. The fractionalization of cabinets may restrict the PM's opportunities to recruit experts. Fractionalized cabinets often experience a high level of intra-coalitional conflicts (Warwick, 1994), which decreases the PM's opportunities to appoint politically experienced experts because their appointments may lead to additional delegation problems. In highly fractionalized cabinets, PMs will prefer to appoint technocrats instead of politically experienced experts (H1b).

The delegation theory also suggests that PMs and presidents have a greater need for ministerial expertise in times of economic crisis (e.g., Alexiadou \& Gunaydin, 2019). Therefore, poor economic situations (i.e., an eco- 
nomic downturn and high inflation) will increase the likelihood of the appointment of both technocrats and politically experienced ministers $(\mathrm{H} 1 \mathrm{c})$. Expert ministers are also more common in times of political crises (compare Pastorella, 2016). In particular, in countries with a low level of democracy, parties are expected to be less consolidated and, as a consequence, less able to control ministerial appointments. Therefore, I expect that technocrats and politically experienced experts are more likely to be recruited in countries with a low level of electoral democracy $(\mathrm{H} 1 \mathrm{~d})$. Unconsolidated party systems are also expected to be the phenomenon of democratic transition. I anticipated that both technocrats and politically experienced experts are more common in the earlier periods of transition, eventually disappearing when the democracies become more consolidated $(\mathrm{H} 1 \mathrm{e})$.

The second set of hypotheses is related to the technocratic populism approach. The literature suggests that technocrats are the best choice for populists during political crises. As for indicators of a political crisis, I will use the minority status and the cabinet's fractionalization. Minority cabinets need to seek parliamentary support beyond their parties, which may be difficult to do in ideologically fractionalized parliaments. As a consequence, minority cabinets are less stable than their majority counterparts. Similarly, in order to avoid a minority status, ideologically diverse parties may build a coalition. Such coalitions are known for a high level of internal conflicts and, as a result, their instability (Warwick, 1994). Under both circumstances, populists will appoint more technocrats to their cabinets to prevent party conflicts $(\mathrm{H} 2 \mathrm{a})$.

The technocratic populist literature also suggests that populists appoint more technocrats during an economic crisis in order to be able to realize unpopular reforms (e.g., Buštíková \& Guasti, 2019). Therefore, l expect that poor economic conditions (i.e., an economic downturn and high inflation) will lead to more technocratic appointments ( $\mathrm{H} 2 \mathrm{~b})$. Finally, studies on technocratic populism have argued that populist parties with technocratic appeal have emerged in the 2000s (Pop-Eleches, 2010). Therefore, I expect that the more years since the democratic transition has passed, the more technocrats will be appointed to cabinets $(\mathrm{H} 2 \mathrm{c})$.

According to the semi-presidentialism approach, popularly elected presidents are more interested in appointing politically inexperienced ministers because of their expertise and their political dependence on the president (e.g., Tavits, 2009). Therefore, l expect that cabinets under popularly elected presidents (i.e., in semipresidential systems) will include more technocrats than politically experienced experts ( $\mathrm{H} 3 \mathrm{a}$ ). The presidential opportunities to appoint experts to cabinets should be even higher if the presidents can discretionally dismiss cabinets (as in Croatia until 2000). I expected, therefore, that if popularly elected presidents have extensive cabinet-dismissal powers, the likelihood of technocratic appointments will be higher, while the probability of appointments of politically experienced experts will be lower (H3b).

The fourth set of hypotheses addresses the communist legacy effects of communist recruitment and specialization patterns on the appointment of experts. I expected that patterns of specialization common in the communist ministries continue being applied after the collapse of communism because of support from both politicians and the general population. Therefore, policy areas that were subject to expert appointments during the late periods of communism will continue being occupied by both technocrats and politically experienced experts after the regime change $(\mathrm{H} 4 \mathrm{a})$. Another indicator of communist portfolio allocation is the type of portfolio to which the minister is appointed during the post-communist period. Following Hough (1973, pp. 142-143), I used three variables to describe the portfolios that were particularly specialized during the communist regime: portfolios of foreign affairs/defense, portfolio of finance/economy, and portfolio of social affairs/education. Because of the small number of ministers in some of these portfolios, I combined the respective portfolios in these categories. I expect that these portfolios will be occupied by both technocrats and politically experienced experts rather than by party politicians (H4b).

The socio-demographic characteristics of the minister were not used in the analysis because the age of the ministers does not show any strong variation and the proportion of female ministers is extremely low in some of our sample countries. Using these variables, empirical models failed to converge (full details are not reported here).

\subsection{Data}

This analysis was based on biographical information about 2,382 ministers from 106 cabinets. The data set encompasses the years 1991 to 2012. It includes information from all 11 post-communist new EU member states: Czech Republic, Hungary, Poland, Slovakia, Estonia, Latvia, Lithuania, Croatia, Bulgaria, Slovenia, and Romania. All of these countries have experienced at least three consecutive lower-chamber elections since the collapse of communism, during which the country's Polity score was six or higher. Thus, I excluded authoritarian regimes. The exception to this rule is Croatia from 1990 until 2000, when its Polity IV score was below six. Because I aimed to analyze the entire population of new EU democracies, this country was included in the analyses.

\subsection{Method}

Two considerations guided the selection of the method. First, because the dependent variables are binary, it is necessary to use a binary logistic regression. Second, I assumed some country-specific heterogeneity not cap- 
tured by the political and individual variables used in this analysis. Therefore, I use fixed effects at the level of countries and calculate robust standard errors adjusted by country.

\subsection{Results}

Descriptively, from the early 1990s until 2012, approximately $44 \%$ of all ministers in post-communist new democracies were experts in the portfolio to which they were appointed. There was, however, considerable variation across countries. For example, Latvia, Hungary, Slovakia, and Croatia comprise the group of countries that are less favorable toward experts in cabinets than other post-communist countries (Figure 1). Bulgarian and Lithuanian cabinets, by contrast, have been most favorable toward experts in cabinets. Moreover, while in Bulgaria and Lithuania, technocrats comprise the largest proportion of expert ministers, politically experienced experts have been more common in Czech and Estonian cabinets.

The results of a binary logistic regression for each dependent variable (i.e., technocrats and politically experienced experts) are reported in Table 1 as odds ratios $(\exp (B))$. The coefficient above 1 means that the determinant increases the probability of appointing the respective group of expert ministers compared to party politicians without expertise, while the coefficient below 1 means that this probability decreases.

Model 1 (Table 1) shows that neither a popularly elected president nor a minority cabinet was a significant determinant of technocratic appointments. In contrast, high cabinet fractionalization decreased the probability of technocratic appointments. A marginal analysis has shown that in single-party governments, the predicted proportion of technocrats was approximately 34\%, in coalitions with six or more partners; this proportion was expected to be below $10 \%$ (full results are not presented here). The likelihood of technocratic appointments was higher if the presidents had extensive non-legislative powers (i.e., discretional cabinet dismissal); in these systems, the predicted proportion of technocrats was $24 \%$. In systems in which the presidents lacked the cabinet dismissal power, this proportion was expected to be $18 \%$ (full results are not presented here).

Neither inflation nor the time since transition nor the electoral democracy index was a significant explanatory factor of technocratic appointments. However, technocrats tend to be often appointed to cabinets in countries experiencing a massive economic crisis and become less widespread in times of economic growth (Figure 2).

The communist legacy determinants, by contrast, provided the most substantial explanation of the appointment of technocratic ministers. If the portfolio was subject to expert appointments during communism, it was three times more likely to be occupied by a technocrat during the post-communist period (Model 1; see also Figure 3). Patterns of specialization used in the communist period appear to survive the regime change, except for appointments to portfolios of foreign affairs and defense. The likelihood of a technocrat to be appointed to the portfolios of finance/economy as well as of the portfolios of social affairs/education was 1.4 times higher than appointments to the other types of portfolios.

Regarding the appointments of politically experienced experts (Table 1, Model 2), the strongest determinants for the appointment of experts with political experience were communist legacies. If the respective portfolio was occupied by an expert during communism, the chances were approximately 2.5 times higher that this

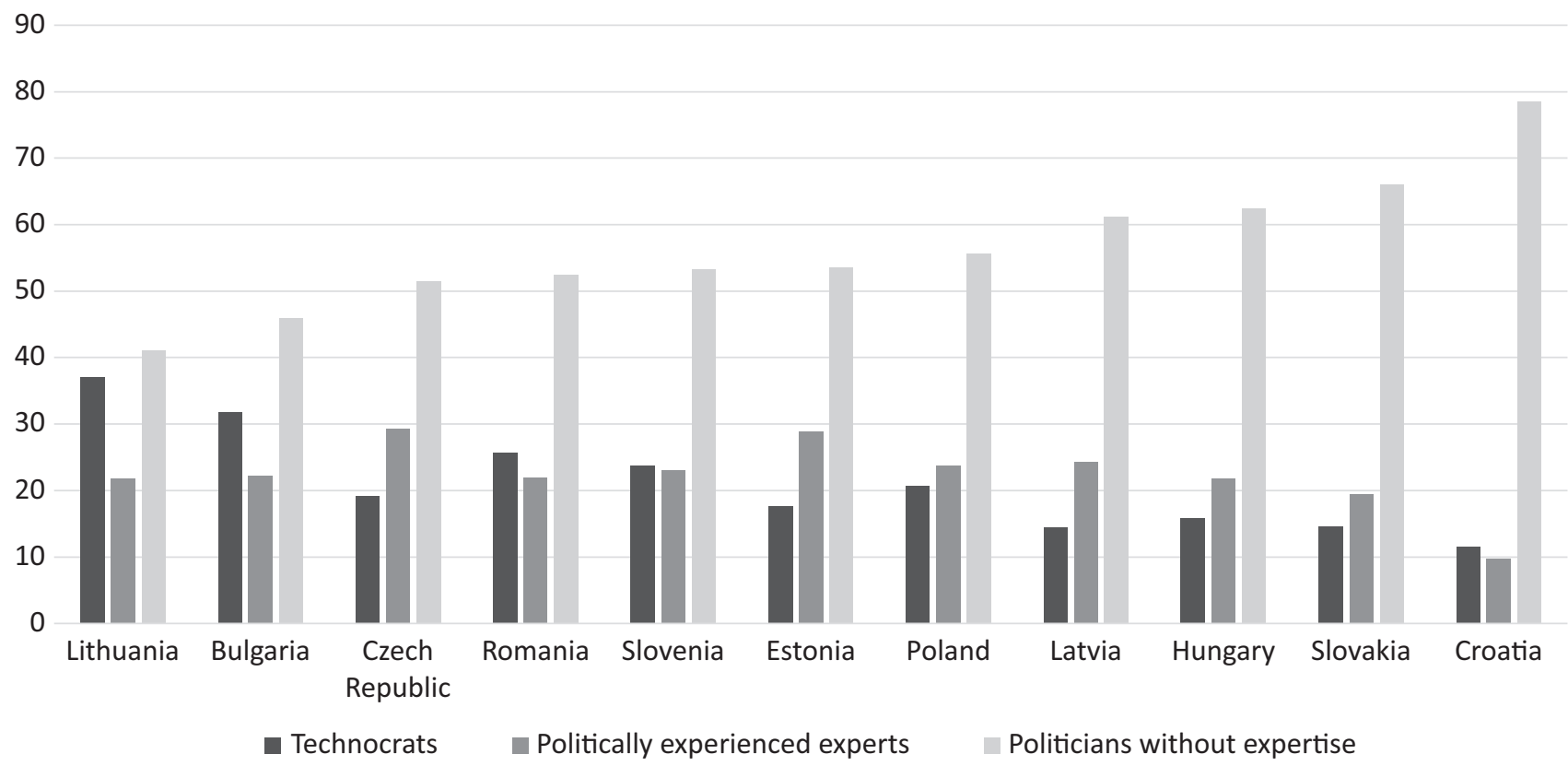

Figure 1. The proportion of technocrats and politically experienced experts in post-communist cabinets (in \%). 
Table 1. The determinants of the appointments of expert ministers to post-communist cabinets (as odds ratios).

\begin{tabular}{|c|c|c|}
\hline & $\begin{array}{l}\text { Technocrats } \\
\text { (Model 1) }\end{array}$ & $\begin{array}{l}\text { Politically experienced experts } \\
\text { (Model 2) }\end{array}$ \\
\hline \multirow[t]{2}{*}{ Minority cabinet } & 0.97 & 0.99 \\
\hline & $(0.20)$ & $(0.12)$ \\
\hline \multirow[t]{2}{*}{ Cabinet fractionalization } & $0.77 * *$ & 1.03 \\
\hline & $(0.06)$ & $(0.05)$ \\
\hline \multirow[t]{2}{*}{ Popularly elected president } & 1.31 & 0.84 \\
\hline & $(0.38)$ & $(0.14)$ \\
\hline \multirow[t]{2}{*}{ Discretional dismissal of cabinets } & $1.39 * * *$ & 1.23 \\
\hline & $(0.12)$ & $(0.25)$ \\
\hline \multirow[t]{2}{*}{ Inflation } & $1.00 *$ & 1.00 \\
\hline & $(0.01)$ & $(0.01)$ \\
\hline \multirow[t]{2}{*}{ Economic growth } & $0.95^{* * *}$ & 1.02 \\
\hline & $(0.01)$ & $(0.01)$ \\
\hline \multirow[t]{2}{*}{ Electoral Democracy Index } & 2.90 & 1.97 \\
\hline & $(2.61)$ & $(1.20)$ \\
\hline \multirow[t]{2}{*}{ Time since the communist transition } & 1.02 & 0.99 \\
\hline & $(0.02)$ & $(0.01)$ \\
\hline \multirow[t]{2}{*}{ Portfolio allocation to an expert during communism } & $3.01 * * *$ & $2.51 * * *$ \\
\hline & $(0.34)$ & $(0.44)$ \\
\hline \multirow[t]{2}{*}{ Portfolio of foreign affairs/defense } & 1.33 & 1.35 \\
\hline & $(0.37)$ & $(0.28)$ \\
\hline \multirow[t]{2}{*}{ Portfolio of finance/economy } & $1.37 * *$ & $1.43^{* *}$ \\
\hline & $(0.86)$ & $(0.18)$ \\
\hline \multirow[t]{2}{*}{ Portfolio of social affairs/education } & $1.39 * * *$ & 1.20 \\
\hline & $(0.11)$ & $(0.17)$ \\
\hline Log psydolikelihood & -965.80 & -1054.52 \\
\hline $\mathrm{N}$ countries & 11 & 11 \\
\hline $\mathrm{N}$ & 2047 & 2047 \\
\hline \multirow[t]{2}{*}{ Linktest hat2 } & -0.07 & -0.43 \\
\hline & $p=(0.13)$ & $p=(0.11)$ \\
\hline Akaike's information criterion & 1951.60 & 2129.04 \\
\hline Bayesian information criterion & 2007.84 & 2185.28 \\
\hline
\end{tabular}

Notes: ${ }^{* * *} \mathrm{p}<0.001,{ }^{* *} \mathrm{p}<0.01,{ }^{*} \mathrm{p}<0.05$; fixed effects at the country level; robust standard errors adjusted by country are in parentheses.

portfolio would be headed by a politically experienced expert than by a politician (Figure 3). Finally, such ministers had a 1.4 times higher chance to be appointed to the portfolio associated with finance and economy.

\section{Survival of Expert Ministers in New Democracies}

Once expert ministers are appointed, questions arise about how long they stay. Each of the discussed approaches expects that ministers without political experience (i.e., technocrats) and politically experienced ministers will have different chances of surviving in cabinet. Delegation theory stresses the minister's political loyalty as the major credential for a cabinet position. Accordingly, ministers with political experience (whether experts or not) should remain in their positions longer than ministers without political experience (i.e., technocrats). Various studies on ministerial careers in parliamentary systems have confirmed this assumption (e.g., Berlinski, Dewan, \& Dowding, 2010; Huber \& Martinez-Gallardo, 2008; Indridason \& Kam, 2008). Politically inexperienced ministers present different issue. PMs can easily dismiss them. Appointment of these ministers during crises allows the PM to shift the blame for electorally unpopular decisions, the cabinet's poor performance, or even scandals (Semenova, 2018; Yong \& Hazell, 2011).

Technocratic populism studies have yet to deal with the issue of ministerial survival. However, researchers argue that populist parties with technocratic appeal are highly personalized (Pop-Eleches, 2010). Therefore, once in government, populist party leaders would assume the prime ministerial position and be the most powerful actors to affect the cabinet survival of technocrats. I expect that provided the continuity of party leadership and party in government, technocrats appointed by populists will remain in their positions longer than ministers with political experience. 


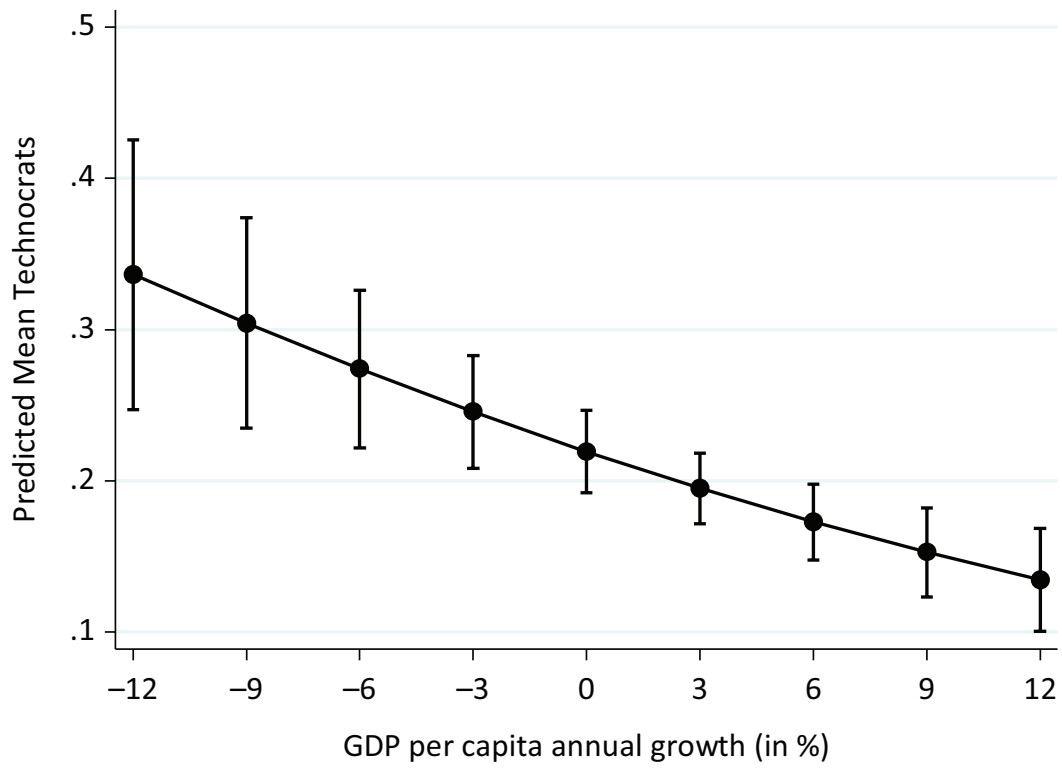

Figure 2. Adjusted predictions for the effect of economic growth on the appointments of technocrats (with $95 \% \mathrm{Cls}$ ). Note: Based on Model 1, all covariates are set at means.

Semi-presidentialism predicts that more politically inexperienced (even non-partisan) ministers to be recruited in these systems. Single-country and comparative studies on ministerial terminations in European semi-presidential countries have revealed that, in these systems, ministers have often been reappointed to subsequent cabinets once the initial cabinet ends (Huber \& Martinez-Gallardo, 2004, p. 39; Semenova \& Dowding, 2019). Researchers assume that in semi-presidential systems, PMs and presidents will try to minimize the probability of intra-executive conflicts. For PMs, a popularly elected president will restrict her discretion to fire ministers to a similar degree as coalitions-in particular, if the minister envisaged for dismissal is a presidential appointee (Semenova \& Dowding, 2019). For presidents, the best strategy to minimize intra-executive conflict is to promote a non-partisan technocrat, who would be able to work with PMs from different parties.

Finally, following the communist legacy argument, one may expect that the appointments of experts to policy areas, which were dominated by experts during the communism, are rationally motivated by the increased demand for expert knowledge for performing in this portfolio. The source for this demand could be the PM, the president, public opinion, or external circumstances (like economic crisis). Therefore, technocrats will

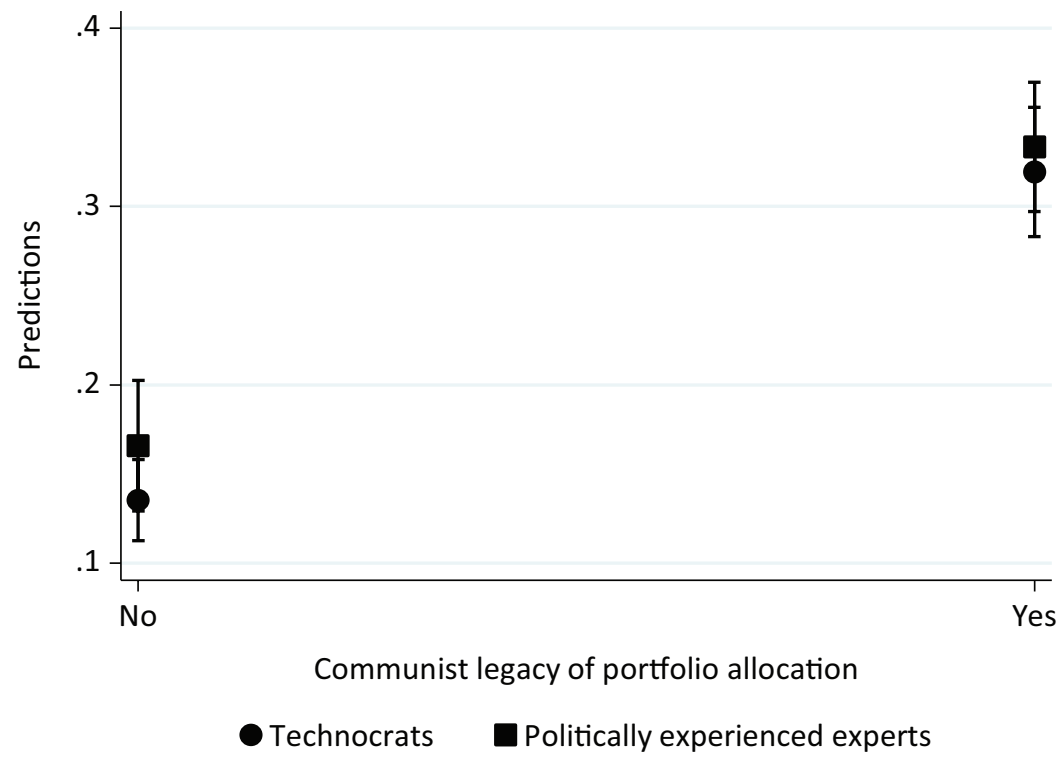

Figure 3. Adjusted predictions for the effect of communist portfolio allocation on the predicted proportion of experts (with $95 \% \mathrm{Cls}$ ). Note: Based on Models 1 and 2, all covariates are set at means. 
remain in their positions longer than party politicians without expertise.

\subsection{Hypotheses and Indicators}

Based on delegation theory, the PM's characteristics are an important factor in the probability of ministerial survival (see the Supplementary File). The first characteristic is whether the PM is partisan. Delegation theory takes for granted that the PM is partisan because she is selected from among members of the ruling coalition. However, post-communist countries have seen non-partisan PMs head a caretaker cabinet or be appointed to a coalition because the coalition partners could not find a candidate acceptable to all. For a partisan PM, a politically experienced minister is the best choice from the delegation perspective. I assume that the opposite holds true for non-partisan PMs who will prefer to work with technocrats instead of politically experienced ministers (H5a). The second factor is the change in the PM (i.e., when the previous cabinet ended, and a new PM is in charge). In this case, the new PM will not be keen to take over politically experienced ministers of her predecessor, except for technocrats ( $\mathrm{H} 5 \mathrm{~b})$. The third factor is the party continuity in government. I assume that if the same party is leading the subsequent cabinet, there will be a high probability that the PM will replace the ministers, in particular politically experienced ones, to introduce new policies or signal change $(\mathrm{H} 5 \mathrm{c})$.

Based on semi-presidentialism studies, the most important factor of ministerial survival is the existence of a popularly elected president. If popularly elected presidents prefer to nominate politically inexperienced ministers, these ministers should be able to survive the change of cabinet and work with different PMs. Therefore, in semi-presidential systems, technocrats are expected to be more durable than their politically experienced colleagues $(\mathrm{H6a})$.

Following technocratic populism studies, the change of PM and party in government will be the most critical factors affecting ministerial durability. Because technopopulist parties prefer to appoint technocrats to cabinets, I expect that if the same party forms the subsequent cabinet, there is a high probability that technocrats will be re-appointed (H7a). Technocrats will also have lower risks of being dismissed if there is any change in the PM's candidacy because they were appointed because of their expertise and should be able to work with different PMs (H7b). Studies have shown that populists appoint more technocrats during economic crises (e.g., Buštíková \& Guasti, 2019). Therefore, improvement of the economic situation will be considered an outcome of technocratic appointments, and technocrats will remain in their positions longer $(\mathrm{H} 7 \mathrm{C})$.

Finally, communist legacies studies suggest that the administration of some policy areas requires more professional expertise than others. Therefore, technocrats will survive in the portfolios traditionally dominated by experts (including finance/economy and foreign affairs/defense) longer than their politically experienced counterparts without expertise (H8a).

I also use a set of control variables derived from ministerial career studies (e.g., Berlinski et al., 2010). Specifically, ministers have higher risks of being dismissed if the cabinet is a minority compared to majority cabinets and if this cabinet is highly fractionalized. Both politically experienced ministers and technocrats will have higher risks of being dismissed if they experienced a gap between appointments because their survival of the PM would be of less importance. Finally, I assume that with the consolidation of democratic regimes in the region, ministerial durability will also be higher because parties will get more control over ministerial appointments (e.g., Semenova, 2018).

\subsection{Method}

Because I am interested in time-to-event, I conducted a survival analysis. The dependent variable is the time of a ministerial appointment in days. A number of considerations guide the selection of the method. First, because I am interested in the effects of the changes in PMs and party continuity in government, the ministerial career has to be understood from a holistic perspective. Each minister may experience a number of failures (i.e., dismissals) over his career. Second, these failures have a natural order (i.e., a minister cannot experience the second dismissal before he has experienced the first one). Therefore, I used the conditional risk set Cox regression model proposed by Prentice, Williams, and Peterson (1981), which takes both considerations into account. In this model, the robust standard errors are stratified by the number of failures. Because the variable Political experience of the minister does not fulfill the proportionality assumptions of the Cox regression (Cox, 1972), I conducted models on sub-samples of ministers stratified by their political experience.

\subsection{Results}

Descriptively, approximately $64 \%$ of all post-communist ministers had been reappointed at least once. The results are presented in Table 2 as hazard ratios. A coefficient above 1 means that the minister has a higher risk of being dismissed; a coefficient below 1-has a lower risk of being dismissed.

The first result was that in new democracies, ministers under popularly elected presidents remained in their positions longer than under indirectly elected presidents, although this effect is marginal for politically experienced ministers. Technocrats (Table 2, Model 1) have higher chances of remaining in cabinet if there is a cabinet under a new PM. Moreover, their re-nomination to a new cabinet was not related to the continuity of the PM's party. For politically experienced ministers (Table 2, Model 2), the risk of being dismissed by a non-partisan PM was 
Table 2. Stratified conditional risk set Cox regression of ministerial survival in post-communist countries (in $\exp (B))$.

\begin{tabular}{|c|c|c|}
\hline & $\begin{array}{l}\text { Minister with no political experience } \\
\text { (Model 1) }\end{array}$ & $\begin{array}{l}\text { Politically experienced ministers } \\
\text { (Model 2) }\end{array}$ \\
\hline \multirow[t]{2}{*}{ Non-partisan PM } & 0.66 & $1.85^{* *}$ \\
\hline & $(0.20)$ & $(0.42)$ \\
\hline \multirow[t]{2}{*}{ The change of the PM } & $0.61 * * *$ & $1.02+$ \\
\hline & $(0.14)$ & $(0.13)$ \\
\hline \multirow[t]{2}{*}{ The PM's party remained in the government } & 1.19 & 1.21 \\
\hline & $(0.31)$ & $(0.17)$ \\
\hline \multirow[t]{2}{*}{ Popularly elected president } & $0.61 * * *$ & $0.65^{*}$ \\
\hline & $(0.07)$ & $(0.05)$ \\
\hline \multirow[t]{2}{*}{ Economic growth } & $0.97^{*}$ & 0.99 \\
\hline & $(0.01)$ & $(0.01)$ \\
\hline \multirow[t]{2}{*}{ Inflation } & 1.00 & 1.00 \\
\hline & $(0.01)$ & $(0.01)$ \\
\hline \multirow[t]{2}{*}{ Communist portfolio allocation } & 1.10 & 0.97 \\
\hline & $(0.11)$ & $(0.08)$ \\
\hline \multirow[t]{2}{*}{ Portfolio of foreign affairs/defense } & 0.98 & 1.12 \\
\hline & $(0.18)$ & $(0.12)$ \\
\hline \multirow[t]{2}{*}{ Portfolio of finance/economy } & 1.10 & $1.24+$ \\
\hline & $(0.17)$ & $(0.14)$ \\
\hline \multicolumn{3}{|l|}{ Control variables } \\
\hline \multirow[t]{2}{*}{ Cabinet fractionalization } & 1.04 & 1.07 \\
\hline & $(0.05)$ & $(0.04)$ \\
\hline \multirow[t]{2}{*}{ Minority cabinet } & 1.14 & $1.21 *$ \\
\hline & $(0.15)$ & $(0.11)$ \\
\hline \multirow[t]{2}{*}{ Gap in the ministerial career } & 1.08 & 0.97 \\
\hline & $(0.28)$ & $(0.14)$ \\
\hline \multirow[t]{2}{*}{ Years since the transition } & $1.03^{*}$ & $1.02 *$ \\
\hline & $(0.01)$ & $(0.01)$ \\
\hline Log pseudolikelihood & -1944.08 & -3505.61 \\
\hline $\mathrm{N}$ of ministers & 633 & 832 \\
\hline $\mathrm{N}$ of failures & 395 & 707 \\
\hline $\mathrm{N}$ of observations & 12485 & 21842 \\
\hline \multirow[t]{2}{*}{ PH global test } & 8.00 (13 df) & \\
\hline & $p=(.84)$ & \\
\hline \multirow[t]{2}{*}{ Linktest hat2 } & 0.10 & \\
\hline & $p=(.58)$ & \\
\hline
\end{tabular}

Notes: $* * * p<0.001, * * p<0.01, * p<0.05,+p<0.1$; robust standard errors stratified by the number of failures.

almost two times higher than by a partisan PM. These ministers had a higher risk of being dismissed if there was a change in the PM and if they headed the portfolio of finance and economy, although in both cases, the effect is marginally significant.

\section{Discussion and Conclusion}

\subsection{Discussion of Empirical Results}

Among the four theoretical approaches discussed in this article, delegation theory and technocratic populism provide better explanations for the appointments of expert ministers and their survival in the cabinet. Confirming expectations derived from delegation theory, the determinants for the appointments of politically experienced experts do not significantly differ from those explaining appointments of party politicians without expertise. Political loyalty appears to be the most important credential for the appointment of both groups of ministers. Furthermore, technocratic appointments are often indeed a sign of a government's dysfunctional development because these ministers have high chances of being appointed during an economic downturn. Regarding the determinants of ministerial durability in new democracies, politically experienced ministers have higher risks of being dismissed by non-partisan PMs and in the case of prime ministerial change.

Delegation theory, however, cannot explain the survival of technocrats (expert ministers without political experience). Technocrats have higher chances of remaining in their positions if there was a change in the PM's 
candidacy. Moreover, they have long careers independently of the continuity of the PM's party in government and the PM's partisan status. However, this durability exists as long as technocrats remain politically unaffiliated-otherwise, their careers will be affected by the determinants applied to politically experienced ministers (see Table 2). These findings support expectations based on the technocratic populism literature.

Communist legacies are the only determinant that explains the appointments of technocrats and politically experienced experts compared to party politicians without expertise. Specifically, the patterns of communist portfolio specialization (e.g., finance and economy) remained in place after the regime change. The policy area of social affairs and education are more often occupied by technocrats than party politicians. I assume that this arrangement is both the result of communist legacies and a recruitment strategy of PMs to shift the blame for any unpopular decisions in these highly politicized policy areas. However, holding these specific portfolios does not protect the minister from dismissal, as our survival analysis has shown. Politically experienced ministers even have a slightly higher risk of being dismissed if they hold finance or economy portfolios.

Finally, against the expectations of semi-presidentialism studies, technocratic appointments are not higher in systems with popularly elected presidents. They are higher in systems that granted their presidents substantial cabinet-dismissal powers. Confirming semipresidentialism studies, technocrats under popularly elected presidents enjoy higher durability than under indirectly elected presidents.

\subsection{Theoretical Implications}

Populists consider themselves proponents of 'ordinary people' who have been betrayed by the political establishment. Corrupt elites have robbed the people of their sovereignty, manipulated them using mediated politics, and failed to discover the common good for the entire society (Caramani, 2017). A newly emerged type of populist parties, technocratic populists, argue that they will use apolitical expertise as the best strategy to provide effective and universal solutions to societal problems. In the cases of party system deconsolidation, democratic decline, and the implosion of the left-right political divide (e.g., Buštíková \& Guasti, 2019; Pop-Eleches, 2010), technocratic appeal and the absence of clear ideological orientation are key elements of the electoral success of such parties in new democracies.

In this article, I have analyzed the technocratic aspect of ministerial appointments and survival in new democracies. What implications can be made from this analysis? First, new democracies provide fruitful ground for techno-populist parties. Because of communist legacies, there is a congruence between technocratic appointments to certain portfolios and public expectations for expertise in government. Public positive atti- tudes toward technocracy and technocrats in government support populists in their strategy to use technocratic appeal.

Second, by cultivating their image of challengers to mainstream parties, populists politicize technocracy. Techno-populist parties do not just promise to bring in more experts to government, which may already be the case in governments formed by mainstream parties. Populists vow to bring in more technocrats; in other words, they promise to bring in outsiders, just like these parties define themselves. Through the politicization of expertise, populists introduce qualitative differences among experts (i.e., being a mainstream versus outsider expert), thereby undermining technocracy's very basis as apolitical governance by expertise and knowledge.

Third, in their technocratic appeal, techno-populist parties are undemocratic and, ironically, elitist at the same time. They are undemocratic because they dismiss the input and processual legitimacy essential in democratic systems and stress the output legitimacy (in the form of policy results). These parties are also elitist because they believe that experts, not voters, can make political decisions and that only they, technocratic populists, can define whom these experts are.

Fourth, technocratic governance exposes the importance of democratic accountability. My results have shown that in new democracies, technocrats survive political changes (e.g., a change of the PM or the PM's party in government). Using the communist legacies argument, I have underlined the positive aspects of technocracy (e.g., policy continuity and skilled decision-making taken by a technocrat). From a democratic perspective, these findings suggest that technocracy may also have negative aspects. As studies on techno-populist parties have shown (e.g., Buštíková \& Guasti, 2019), once elected, these parties have often tried to reduce the opportunities for political participation and representation and increase their chances to consolidate power. Technocracy is democratically unaccountable. Technocrats who help populists weaken the institutes of mediated politics and undermine procedural legitimacy by applying their expert knowledge are an underrated threat to democracy.

\subsection{Further Research}

The presented results show the ramifications of ministerial appointments, party politics, populism, and technocracy in former communist countries. Extant studies on ministerial appointment and survival have ignored the importance of the minister's expertise in new democracies (e.g., Neto \& Strøm, 2006). This aspect has to be taken into account in further comparative studies. Moreover, none of the studies on ministerial careers in former communist countries (e.g., Schleiter \& Morgan-Jones, 2009) has dealt with the effects of communist legacies. This issue warrants greater study in order to identify the mechanisms behind this persistence. 
Further studies are required to explain the variation in the country-specific preferences for technocrats or politically experienced experts in the region. Whether it is institutions, political culture, public opinion, or other factors that determine who is appointed needs to be examined in a more detailed way. Finally, this research opens new avenues for studying the effect of technocracy on policy-making, public perception of governments, and democratic stability. For example, the use of technocracy by populist parties while in government presents a topic that warrants further research.

\section{Acknowledgments}

I thank Michael Edinger and the participants of the international workshop "Anti-Elitism: Varieties of Technocratic Populism around the World" (University of Jena) for their suggestions on earlier versions of this article, and very gratefully acknowledge the helpful comments of the co-editors of this thematic issue and two anonymous referees. Part of the data collection for this article was funded by the research grant from the Jena Graduate Academy, Germany (grant reference no. JGA-2019/02).

\section{Conflict of Interests}

The author declares no conflict of interests.

\section{Conflict of Interests}

Supplementary material for this article is available online in the format provided by the author (unedited).

\section{References}

Alexiadou, D., \& Gunaydin, H. (2019). Commitment or expertise? Technocratic appointments as political responses to economic crises. European Journal of Political Research, 58(3), 845-865.

Bakema, W. E., \& Secker, I. P. (1988). Ministerial expertise and the Dutch case. European Journal of Political Research, 16(2), 153-170.

Berlinski, S., Dewan, T., \& Dowding, K. (2010). The impact of individual and collective performance on ministerial tenure. The Journal of Politics, 72(2), 559-571.

Bertsou, E., \& Caramani, D. (Eds.). (2020). The technocratic challenge to democracy. London and New York, NY: Routledge.

Bertsou, E., \& Pastorella, G. (2017). Technocratic attitudes: A citizens' perspective of expert decisionmaking. West European Politics, 40(2), 430-458.

Bickerton, C., \& Invernizzi Accetti, C. (2017). Populism and technocracy: Opposites or complements? Critical Review of International Social and Political Philosophy, 20(2), 186-206.

Blondel, J., \& Thiébault, J.-L. (Eds.). (1991). The profession of government minister in Western Europe. New York,
NY: St. Martin's Press.

Buštíková, L., \& Guasti, P. (2019). The state as a firm: Understanding the autocratic roots of technocratic populism. East European Politics and Societies, 33(2), 302-330.

Camerlo, M., \& Pérez-Liñán, A. (2015). The politics of minister retention in presidential systems: Technocrats, partisans, and government approval. Comparative Politics, 47(3), 315-333.

Caramani, D. (2017). Will vs. reason: The populist and technocratic forms of political representation and their critique to party government. The American Political Science Review, 111(1), 54-67.

Cox, D. R. (1972). Regression models and life tables. Journal of the Royal Statistical Society, Series B (Methodological), 34(2), 187-220.

de la Torre, C. (2013). Latin America's authoritarian drift: Technocratic populism in Ecuador. Journal of Democracy, 24(3), 33-46.

Dowding, K., \& Dumont, P. (Eds.). (2009). The selection of ministers in Europe: Hiring and firing. London and New York, NY: Routledge.

Elgie, R. (1999). The politics of semi-presidentialism. In R. Elgie (Ed.), Semi-presidentialism in Europe (pp. 1-21). Oxford: Oxford University Press.

Hanley, E., \& Treiman, D. J. (2005). Recruitment into the Eastern European communist elite: Dual career paths. Research in Social Stratification and Mobility, 23, 35-66.

Harasymiw, B. (1984). Political elite recruitment in the Soviet Union. London: MacMillan Press.

Havlík, V. (2019). Technocratic populism and political illiberalism in Central Europe. Problems of PostCommunism, 66(6), 369-384.

Hough, J. F. (1973). The bureaucratic model and the nature of the Soviet system. Journal of Comparative Administration, 5(2), 134-167.

Huber, J. D. (2000). Delegation to civil servants in parliamentary democracies. European Journal of Political Research, 37(3), 397-413.

Huber, J. D., \& Martinez-Gallardo, C. (2004). Cabinet instability and the accumulation of experience: The French fourth and fifth republics in comparative perspective. British Journal of Political Science, 34(1), 27-48.

Huber, J. D., \& Martinez-Gallardo, C. (2008). Replacing cabinet ministers: Patterns of ministerial stability in parliamentary democracies. American Political Science Review, 102(2), 169-180.

Indridason, I., \& Kam, C. (2008). Cabinet reshuffles and ministerial drift. British Journal of Political Science, 38(4), 621-656.

Kitschelt, H. (1995). Formation of party cleavages in post-communist democracies: Theoretical propositions. Party Politics, 1(4), 447-472.

Lewis, P. (2002). Political parties in post-communist Eastern Europe. London and New York, NY: Routledge.

McDonnell, D., \& Valbruzzi, M. (2014). Defining and 
classifying technocrat-led and technocratic governments. European Journal of Political Research, 53(4), 654-671.

Mudde, C. (2004). The populist zeitgeist. Government and Opposition, 39(4), 541-563.

Neto, O., \& Strøm, K. (2006). Breaking the parliamentary chain of delegation: Presidents and non-partisan cabinet members in European democracies. British Journal of Political Science, 36(4), 619-643.

Pastorella, G. (2016). Technocratic governments: Power, expertise and crisis politics in European democracies (Unpublished Doctoral dissertation). The London School of Economics and Political Science, London, United Kingdom.

Pop-Eleches, G. (2010). Throwing out the bums: Protest voting and unorthodox parties after communism. World Politics, 62(2), 221-260.

Prentice, R. L., Williams, B. J., \& Peterson, A. V. (1981). On the regression analysis of multivariate failure time data. Biometrika, 68(2), 373-379.

Roberts, K. M. (1995). Neoliberalism and the transformation of populism in Latin America: The Peruvian case. World Politics, 48(1), 82-116.

Schleiter, P., \& Morgan-Jones, E. (2009). Party government in Europe? Parliamentary and semi-presidential democracies compared. European Journal of Political Research, 48(5), 665-693.

Semenova, E. (2015). Parliamentary party switching: A specific feature of post-communist parliamentarism? Zeitschrift für Parlamentsfragen, 46(2), 272-291.

Semenova, E. (2018). Recruitment and careers of minis- ters in Central Eastern Europe and Baltic countries. In A. Costa Pinto, M. Cotta, \& P. Tavares de Almeida (Eds.), Technocratic ministers and political leadership in European democracies (pp. 173-202). London: Palgrave Macmillan.

Semenova, E., \& Dowding, K. (2019). The effects of institutional rules on cabinet and ministerial durability. Evidence from Central and Eastern European countries. Manuscript submitted for publication.

Strøm, K., Müller, W. C., \& Bergman, T. (Eds.). (2008). Cabinets and coalition bargaining: The democratic life cycle in Western Europe. Oxford: Oxford University Press.

Tavits, M. (2005). The development of stable party support: Electoral dynamics in post-communist Europe. American Journal of political science, 49(2), 283-298.

Tavits, M. (2009). Presidents with prime ministers: Do direct elections matter? Oxford: Oxford University Press.

Valbruzzi, M. (2018). When populists meet technocrats. The Italian innovation in government formation. Journal of Modern Italian Studies, 23(4), 460-480.

Warwick, P. (1994). Government survival in parliamentary democracies. Cambridge: Cambridge University Press.

Whitefield, S. (2002). Political cleavages and postcommunist politics. Annual Review of Political Science, 5(1), 181-200.

Yong, B., \& Hazell, R. (2011). Putting goats amongst the wolves: Appointing ministers from outside parliament. London: UCL Constitution Unit.

\section{About the Author}

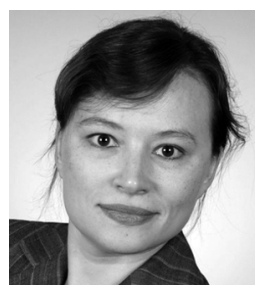

Elena Semenova is Assistant Professor at the Free University of Berlin and Adjunct Professor of Political Science at the University of Jena, Germany. She previously held academic appointments at the Moscow State University and Humboldt University of Berlin. She has published comparative studies on parliamentary recruitment and ministerial careers in post-communist countries, party switching, and political psychology of leadership. 